$\stackrel{\odot}{\text { III }}$

\title{
HUMANISTA W DOBRYM KONTAKCIE, CZYLI O TUTORINGU AKADEMICKIM
}

ABSTRACT. Julita Wojciechowska, Humanista w dobrym kontakcie, czyli o tutoringu akademickim [A humanist in good contact] edited by M. Obrębska, G. Dziamski, "Człowiek i Społeczeństwo" vol. XLIX: Humanistyka jutra [Humanities of Tomorrow], Poznań 2020, pp. 215-222, Adam Mickiewicz University. ISSN 0239-3271.

The aim of the article is to present the basic idea of academic tutoring. This method allows for personalized and in-depth use of experience - based and taught teaching tools by developed in modern humanities in academic teaching.

Julita Wojciechowska, Uniwersytet im. Adama Mickiewicza w Poznaniu, Wydział Psychologii i Kognitywistyki, Zakład Psychologii Rozwoju, ul. Szamarzewskiego 89/AB, 60-658 Poznań, julita. wojciechowska@amu.edu.pl, ORCID: https://orcid.org/0000-0003-1678-3954.

Naukę uprawiać, a nie kochać ludzi, to zapalać lampę, zamykajq̨c oczy.

Przysłowie chińskie

\section{Wprowadzenie}

Jako nauczyciel akademicki od ponad dwóch dekad staram się, aby na uczelni w procesie nauczania studentów mieć wkład w dwa ważne procesy: pierwszy to nabywanie przez studentów wiedzy i umiejętności, zarówno na specjalistycznym, jak i ogólnym, uniwersalnym poziomie, drugi to rozwój 
kompetencji społecznych związanych z przygotowaniem studenta i do roli akademickiego badacza, i do zawodowej aplikacji zdobywanej wiedzy. Szczególnie ten drugi nurt wydaje mi się ważny i elementarny w przygotowywaniu do profesji związanych z kształtowaniem, badaniem, interweniowaniem bezpośrednim czy pośrednim w życie jednostek czy społeczności.

W dobie ukierunkowania roli nauczyciela akademickiego poprzez różnorodne naciski instytucjonalne na przede wszystkim prowadzenie i promowanie swoich badań naukowych długo szukałam formuły, która pozwoliłaby mi z satysfakcją łączyć obie działalności uniwersyteckie: naukową i dydaktyczną, globalną i lokalną. W 2018 roku mała grupa pracowników naukowych z naszego wówczas Instytutu Psychologii UAM wzięła udział w Szkole Tutorów Collegium Wratislaviense, a w roku 2020 kończymy już drugą edycję Szkoły Tutorów Akademickich już na Wydziale Psychologii i Kognitywistyki UAM i mamy na wydziale swoją „Radę Tutorów” dla obu kierunków studiów.

Celem mojego artykułu jest przybliżenie idei tutoringu jako rozwiązania pozwalającego na budowanie relacji ze studentami i jednoczesnego rozwoju zarówno własnego, jak i naszych podopiecznych w obszarze naukowym (tu mówimy wówczas o tutoringu naukowym) i społecznym, emocjonalnym, lub/i też w obszarze organizacji, rozumienia swojego uczenia się i studiowania (ten tutoring częściej określa się jako rozwojowy, por. Brzezińska, Rycielska, 2009). Formuła tutoringu pozwala na łączenie obu obszarów zarówno we współpracy ze studentami jako grupą jak i w pracy indywidualnej (por. tabela 1).

Tab. 1. Kluczowe obszary pracy w tutoringu akademickim i rozwojowym

\begin{tabular}{|l|l|}
\hline \multicolumn{1}{|c|}{ Tutoring akademicki } & Tutoring rozwojowy \\
\hline - Odkrywanie osiowych problemów & • Odkrywanie i stabilizowanie kluczowych warto- \\
w danej dziedzinie & ści życiowych \\
• Odróżnianie kwestii ważnych od & • Ujawnianie, werbalizowanie, dyskutowanie \\
peryferyjnych, problemów ogól- & własnego podobieństwa i unikatowości względem \\
nych od szczegółowych & innych, również tutora \\
• Konstruowanie indywidualnej & • Nauka eksploracji treści budzących zainteresowa- \\
struktury wiedzy & nie, tworzenie hipotez, rozwijanie myślenia \\
- Tworzenie własnych wariacji & - Zachęcanie do podejmowania zobowiązań, \\
wewnątrz projektów naukowych & wywiązywania się z umów, przewidywania kon- \\
tutora & sekwencji własnego działania i myślenia \\
\hline
\end{tabular}

Źródło: opracowanie własne na podstawie Brzezińska, Rycielska, 2009

Tutoring uważam za istotne rozszerzenie oferty dydaktycznej szczególnie kierunków humanistycznych i społecznych ze względu na integrację narzędzi naukowych z doświadczeniem indywidualnym. Moim zdaniem 
metoda ta sprawdza się w ugruntowywaniu stosowania nauki do rozumienia najpierw własnej, potem szerszej rzeczywistości, a przez to utrwala naukowe, pogłębione podejście do świata w ogóle (Czekierda, 2009).

\section{Tutoring w tradycji akademickiej}

Tutoring jako metoda rozwoju wywodzi się z krajów anglosaskich, głównie z tradycji edukacji prowadzonej na uniwersytetach w Oksfordzie i Cambridge, teraz stosowany jest jako jedna z metod na wielu uczelniach na całym świecie (Palfreyman, 2008). Bywa zróżnicowana pod względem organizacyjnym, natomiast zachowuje swoją podstawową ideę, jaką jest bezpośrednia praca tutora z uczniem lub studentem (tutee'm) podczas najczęściej jednego semestru poświęconego na analizę wybranego zagadnienia w oparciu o preferencje tutora i zainteresowania oraz zasoby tutee'go. Tutoring jest ukierunkowany na proces integrowania rozwoju intelektualnego w zakresie wiedzy, umiejętności akademickich z rozwojem postaw, wrażliwości, pogłębionej kontekstowo analizy akademickiego problemu, który przewodzi spotkaniom i wspólnej pracy (Czekierda, 2015).

Skoncentrowanie tutora na zasobach, zainteresowaniach i chęciach studenta w doborze zakresu pracy z jednej strony jest oczywiste, a z drugiej nie zawsze obecne w codziennych spotkaniach ze studentami. Tutoring jest formułą pracy dobrowolnej, nienarzuconej, wybieranej przez zwykle część studentów, nie wszystkich. Na pracę w formule tutoringowej wyrażają zgodę obie strony, to znaczy tutor jest kimś interesującym dla studenta, ale i tutor podejmuje decyzję, czy z tym studentem chce realizować tutoring. Formuła ta pozwala w warunkach uniwersyteckich, czyli, jakby nie patrzeć, coraz bardziej masowych, doświadczać nie tylko przypadkowo, ale i systemowo interakcji, w której głównym motywem jest wybór, decyzja i determinacja uświadomiona zarówno po stronie studenta, jak i wykładowcy. Deklaratywnie wszyscy jesteśmy tam, gdzie chcemy być: studenci się uczą, bo chcą, a my nauczamy, bo podjęliśmy taką decyzję, na co dzień jednak, w zalewie zajęć, zaliczeń i egzaminów, konfliktów ról czy liczby studentów, ta decyzyjność często nie jest odczuwalna. Tutoring wiąże się z zawieraniem kontraktu ze studentem na określony czas, na formułę pracy, na zdefiniowane zobowiązania i sposób komunikacji. Stąd też nie tylko sam tutee ma okazję poczuć się osobą potraktowaną indywidualnie, wykładowca też wychodzi z roli „trybika” w wielkiej uczelnianej machinie. Jest wybrany i sam wybiera w tej relacji (por. Szala, 2015; Fingas, 2015). 
Poznanie tutoringu i podjęcie się jego realizacji na uczelni było też dla mnie powrotem do pierwotnej (młodzieńczej, bym powiedziała) idei siebie jako nauczyciela, osoby myślącej i uczącej myślenia, osoby badającej i uczącej badania, osoby krytycznej i wskazującej na pułapki w osądach i przekonaniach. W dobie zarówno szybko zmieniających się, jak i niejasnych reguł oceniania mnie jako pracownika naukowego znalazłam zakotwiczenie w relacji nauczania, która też pierwotnie do uniwersytetu mnie przyciągnęła: współpracuję ze studentami, poznaję ich potrzeby i mogę profesjonalnie odpowiedzieć na nie w procesie edukacyjnym. Tutoring pozwala mi na praktyczne osadzenie perspektywy humanistycznej w relacji tak często lekceważonej gdzie indziej, pozwala na wyjście z machiny „zaliczania i zdawania” do indywidualnej relacji nauczania myślenia i wrażliwości.

I tak tego się nie zrobi masowo. Idea tutoringu budzi wiele zastrzeżeń co do sposobu uruchamiania (dobrowolność), jak i finasowania (bo to praca w małych grupach lub tylko w relacjach jeden na jeden, por. Godlewski, 2015), tym niemniej włączenie tego w tradycyjny nurt nauczania akademickiego daje zarówno szanse rozwoju studentowi, jak i nauczycielowi.

\section{Główne cele i metody pracy podczas tutoriali}

Jako psycholog wychodzę z założenia, że edukacja służy rozwojowi jednostki. W tym duchu psychologiczne aspekty tutoringu opisały Anna Brzezińska i Ludmiła Rycielska (2009).

Zarówno w ich opracowaniu, jak i innych, jako podstawowe narzędzia pracy w tutoringu wskazuje się esej tutorski, analizę przypadku, analizę zadań rozwojowych. Wykorzystywane narzędzia są zbieżne z niektórymi narzędziami coachingowymi, zwłaszcza w zakresie odkrywania mocnych stron tutee'go i analizowania przeszkód w ich rozwijaniu. Narzędzia rozwojowe są podstawą tutoringu rozwojowego. W tutoringu akademickim, bardziej ukierunkowanym na kompetencje związane w uprawianiem danej gałęzi nauki, pod kierunkiem tutora student uczy się szukania danych, analizowania ich, organizacji procesu analizy danych, szukania własnych rozwiązań czy lektur, pisania prac problemowych, takich jak na przykład esej tutorski, skłaniających do rozstrzygnięcia jakiegoś naukowego problemu. Prace te są w rozmowie z tutorem analizowane i poddane dyskusji, co ważne: służą raczej jako drogowskaz do dalszej pracy (ocena formatywna) niż jako podstawa oceny uzyskanego efektu (ocena sumatywna). 
Głównym celem tutoringu jest zbudowanie relacji, w ramach której będzie możliwy i bezpieczny rozwój zarówno intelektualny, jak i społeczno-emocjonalny studenta. Cała praca na tutorialach ma na celu zintegrowanie tych dwóch obszarów uczenia się w jedno doświadczenie.

Bezpieczeństwo i zaufanie ma większe szanse na zaistnienie, kiedy szczególnie dbamy o aktywny i dobrowolny udział studenta oraz partnerskie i formatywne nastawienie wykładowcy.

Jako interakcja edukacyjna tutoring mieści się według Brzezińskiej (2000) w modelu współpracy, w którym nauczyciel i student dopełniają się w ramach swoich zasobów, dynamika jest oparta na różnicy w kompetencjach i jednoczesnym partnerstwie we współprowadzeniu procesu tutoringowego. W tej relacji nie ma nakazów ani zakazów, tylko oparte na wyborze i decyzjach umowy, renegocjowane w razie potrzeby przez dwie strony (Fingas, 2015).

\section{Tutoring jako metoda rozwoju studenta}

Na początek warto zaznaczyć, że tutoring jest metodą rozwojową i wszystkie włączone w tę formułę narzędzia również mają takie zadanie. Nie służy sprawdzaniu i ocenianiu wiedzy czy umiejętności studenta, a przynajmniej nie do tego używa narzędzi diagnostycznych, kwestionariuszy czy zadań w trakcie jego trwania. Każda praca do zrobienia w ramach spotkań tutoringowych czy między nimi służy procesowi rozwoju w obszarze, na który się tutor ze studentem umówił.

Tutoring pozwala na uczestniczenie w spersonalizowanej edukacji tak zwanym osobom przeciętnym. Na uczelni zazwyczaj mamy ścieżki dla studentów zdolnych: dostają stypendia, organizują się w koła naukowe, są zapraszani do współpracy przy grantach, piszą swoje studenckie projekty, organizują studenckie konferencje. Mamy też systemy wsparcia studentów ze specyficznymi potrzebami: czy to w związku z niepełnosprawnościami czy trudnościami w procesie uczenia się, na podstawie chorobowych czy rozwojowych deficytów. Tutoring pozwala na odkrycie największej rzeszy studentów z ich pomysłami i zasobami, bazując nie na wyjątkowości procesu rozwoju, tylko na indywidualnej deklaracji dobrowolności. Wystarczy, że będą chcieli zgłosić się do tutora, napiszą esej na zgłoszenie i zostaną przyjęci (Czekierda, 2009).

Tutoring, oprócz formuły spotkań indywidualnych, jest otwarty w swojej klasycznej formule na dyskusje grupowe, pracę w parach, co we współczesnych czasach również jest rzadkim, a cennym doświadczeniem w procesie 
uczenia się naszych studentów. Jednoczą się nie tylko wokół tego, co trzeba zaliczyć, ale i wokół własnych pasji i zainteresowań, swojego stylu myślenia i podejścia do problemu. Tak konstruowane spotkania na przykład w ramach seminariów magisterskich pozwalają na ćwiczenia również wystąpień publicznych, reagowanie na czyjeś i własne emocje w dyskusji, szukanie i ujawnianie argumentów (por. Clark, 2008).

\section{Tutoring jako metoda rozwoju nauczyciela}

Tutoring, jak już wcześniej wspomniałam, jest metodą pracy, która daje i satysfakcję, i ogląd, i kontrolę sposobu uczenia się, myślenia i wnioskowania studenta w danej dziedzinie. Nie jest realnie jedynie możliwą i docelowo jedyną formą organizacji dydaktyki na współczesnych uczelniach, ale znakomicie uzupełnia formy grupowe i nauczanie zarówno w wersji podającej, jak i metodami aktywizującymi czy projektowymi.

Dla wykładowcy to okazja do bezpośredniego i wyraźnego uczestniczenia w rozwoju studenta w sposób bardziej odczuwalny niż w metodzie pracy z dużymi grupami. W takich sytuacjach spotkania sam na sam ze studentami dotyczą częściej jakichś spraw wyjątkowych i też częściej o charakterze negatywnym (spóźnienia z pracą zaliczeniową, nadliczbowe nieobecności). Spotkania ze studentem w ramach tutoringu to spotkania z zasady pozytywne, służące odkryciu mocnych stron, zainteresowań, posiadanych już zdolności czy zasobów do rozwoju nowych talentów. Przy okazji poznajemy i braki, i deficyty studenta, ale to nie one stanowią cel spotkań czy tematów rozmów.

Tutoring to sztuka prowadzenia rozmowy, rzeczowej dyskusji, zadawania pytań, omawiania sposobów rozwiązywania problemów, czyli w zasadzie istota nauczania. Ważna w nich jest dobrowolność również po stronie nauczyciela, zwłaszcza w polskich warunkach, gdzie to jest nadal nowość i rzadkość, ale też dzięki temu tutorem zostaje się, jeśli się tego chce. Zarówno obligatoryjne bycie tutorem, jak i tutorowanym neguje podstawową zasadę $\mathrm{w}$ tej metodzie, czyli dokonywania wyboru, na bazie którego dynamizuje się cała dalsza współpraca obu stron.

Dobrowolność bycia tutorem daje również nieoczywiste skutki, jak na przykład rozwój społeczności, grupy nauczycieli akademickich myślących o dydaktyce, studentach i swojej dla nich roli w podobny sposób. Satysfakcjonujące jest nie tylko to, że pracuje się inaczej i konstruktywniej ze studentem, ale i też to, że nie jest się już w tej pracy ze swoją ideą, z doświadczeniami, 
samemu, co niejednokrotnie towarzyszy jako codzienne doświadczenie pracy na uniwersytecie.

Decyzja o wprowadzeniu tutoringu daje szansę na zbudowanie, czasami od podstaw, wewnętrznej społeczności („rady”), która organizuje się wokół tutoriali, wokół ich omawiania, superwizowania, dalszego rozwoju nowych narzędzi. Bycie w grupie nie tylko pod względem zadaniowym, ale i społecznym staje się nowym źródłem energii i entuzjazmu dla nauczycieli akademickich, czy nauczycieli w ogóle (Czekierda, 2009: 17).

\section{Podsumowanie}

Rozważania nad charakterem, skutecznością i jakością dydaktyki na uczelniach wyższych toczą się w gremiach na różnych poziomach nie od dziś. W dobie bezprecedensowego kryzysu humanistyki nie tylko poza murami uczelni, ale i w dyskusji na temat jej miejsca wewnątrz akademii szczególnie istotne jest przypomnienie, skąd nasi absolwenci mogą czerpać przekonanie o sensie zajmowania się językiem, literaturą, szeroką i pogłębioną analizą powszechnych zjawisk i ludzkich przeżyć. Moim zdaniem, idąc śladem Lwa Wygotskiego, jeśli chcemy ukształtować humanistę, potrzebujemy miejsca i relacji, w której doświadczy on funkcjonalności, realnego „pożytku” dla siebie z narzędzi, jakie humanistyka proponuje. Relacja tutorska z racji i swojej otwartości na wszelkie dziedziny, i jednocześnie uporządkowanej metodycznej struktury (por. Ryan, 2008; Mirfield, 2008; Pearson, 2008; Dawkins, 2008; Fox, 2008; Probert, 2008) jest jedną z dróg odzyskiwania miejsca myślenia humanistycznego, erudycji, argumentacji, analizy w kształceniu uniwersyteckim w połączeniu z doświadczeniem, zintegrowania nauki z codziennym ludzkim doświadczeniem studenta i nauczyciela. Innymi słowy, wychowanie humanisty wymaga dobrego kontaktu z ukształtowanym już humanistą i to nie tylko za pośrednictwem publikacji naukowych, ale i bezpośredniego nauczania rozwiązywania problemów.

\section{Literatura}

Brzezińska, A. (2000). Psychologia wychowania. W: J. Strelau (red.), Psychologia. Podręcznik akademicki (s. 223-253), t. 3. Sopot: Gdańskie Wydawnictwo Psychologiczne.

Brzezińska, A., Rycielska, L. (2009). Tutoring jako czynnik rozwoju ucznia i nauczyciela. W: M. Budzyński, J. Traczyński, P. Czekierda, Z. Zalewski, A. Zembrzuska (red.), Tutoring w szkole. Między praktykq a teoriq zmiany edukacyjnej (s. 19-30). Wrocław: TEO. 
Clark, J. (2001). The Oxford tutorial: The students' perspective. W: D. Palfreyman (red.), The Oxford Tutorial: 'Thanks, you taught me how to think'. Oxford: Oxford Centre for Higher Education Policy Studies.

Czekierda, P. (2009). Co możemy zyskać w perspektywie społecznej, wprowadzając tutoring do szkoły? W: M. Budzyński, J. Traczyński, P. Czekierda, Z. Zalewski, A. Zembrzuska (red.), Tutoring w szkole. Między praktykq a teoriq zmiany edukacyjnej (s. 15-18). Wrocław: TEO.

Czekierda, P. (2015). Czym jest tutoring? W: P. Czekierda, B. Fingas, M. Szala (red.), Tutoring. Teoria. Praktyka. Studia przypadków (s. 15-36). Warszawa: Wolters Kluwer.

Dawkins, R. (2008). Evolution in biology tutoring. W: D. Palfreyman (red.), The Oxford Tutorial:'Thanks, you taught me how to think'. Oxford: Oxford Centre for Higher Education Policy Studies.

Fingas, B. (2015). Fundamenty i źródła tutoringu. W: P. Czekierda, B. Fingas, M. Szala (red.), Tutoring. Teoria. Praktyka. Studia przypadków (s. 37-61). Warszawa: Wolters Kluwer.

Fox, L. (2008). Tutorials in greats and history: The Socratic method. W: D. Palfreyman (red.), The Oxford Tutorial:'Thanks, you taught me how to think'. Oxford: Oxford Centre for Higher Education Policy Studies.

Godlewski, D. (2015). Tutoring nie jest tani: dlaczego się opłaca i jak go finansować? W: P. Czekierda, B. Fingas, M. Szala (red.), Tutoring. Teoria. Praktyka. Studia przypadków (s. 89-111). Warszawa: Wolters Kluwer.

Mirfield, P. (2008). Teaching law, learning law: Growing up intellectually. W: D. Palfreyman (red.), The Oxford Tutorial:'Thanks, you taught me how to think'. Oxford: Oxford Centre for Higher Education Policy Studies.

Palfreyman, D. (2008). Higher education, liberal education, critical-thinking, academic discourse, and the Oxford tutorial as sacred cow or pedagogical gem. W: D. Palfreyman (red.), The Oxford Tutorial:'Thanks, you taught me how to think'. Oxford: Oxford Centre for Higher Education Policy Studies.

Pearson, R. (2008). Modern linguists as multi-taskers. W: D. Palfreyman (red.), The Oxford Tutorial:'Thanks, you taught me how to think'. Oxford: Oxford Centre for Higher Education Policy Studies.

Probert, P. (2008). Engineering the tutorial experience. W: D. Palfreyman (red.), The Oxford Tutorial:'Thanks, you taught me how to think'. Oxford: Oxford Centre for Higher Education Policy Studies.

Szala, M. (2015). Praca tutorska i proces stawania się tutorem. W: P. Czekierda, B. Fingas, M. Szala (red.), Tutoring. Teoria. Praktyka. Studia przypadków (s. 62-88). Warszawa: Wolters Kluwer. 